\title{
The Biblical Hebrew infinitive
}

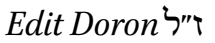 \\ The Hebrew University of Jerusalem, Jerusalem, Israel
}

\begin{abstract}
The paper proposes that the same functional categories which determine the inflection of the Biblical Hebrew finite verb also determine the feature specification of the Biblical Hebrew infinitive. This proposal depends both on demonstrating that the infinitive is a verb, rather than a noun (or a verbal noun), as traditionally assumed, and on showing that the functional categories that embed the infinitive are clausal rather than nominal. The article starts by examining the traditional distinction between the Infinitive Absolute and Infinitive Construct, and makes an argument for a single infinitive, with two allomorphs. The former is a verb marked as [+Mood], while the latter is marked as [-Mood], and both are also specified for two other clausal functional categories: $\mathrm{T}$ and Asp/Mod. These two latter categories determine a 4-way classification of finite/infinitival verbs: [+T+Asp/Mod], [+T-Asp/Mod], [-T+Asp/Mod], [-TAsp/Mod]. This classification determines a concomitant 4-way alternation of attachment options of subject and/or object clitics to the verb: [+subj.cl.+Obj.cl.], [+subj.cl.Obj.cl.], [-subj.cl.+Obj.cl.], [-subj.cl.-Obj.cl.], and moreover accounts for the distribution of the different verb forms.
\end{abstract}

\section{Keywords}

finiteness - event nominals - infinitive - clause - mood - tense - aspect - modality Biblical Hebrew

\section{Introduction}

Biblical Hebrew $(\mathrm{BH})$ verbal forms manifest rich inflection within the finite clause, encoding the functional categories of temporality $(\mathrm{T})$, mood (Mood), grammatical aspect (Asp), and modality (Mod). These categories have been widely discussed in the literature, and their relative role is still under debate 
(recently Hatav 1997, 2008, Joosten 2002, Cook 2006, 2012 and others). In particular, Asp and Mod have proven hard to disentangle in $\mathrm{BH}$, and the present work will reflect this by assuming a composite Asp/Mod category. But what has not so far been proposed is that the same categories regulate the use of the infinitive as well. It is the aim of the present paper to demonstrate the function of these categories within the infinitive clause. I argue that $\mathrm{BH}$ has a single infinitive category, which is specified for different combinations of T, Mood, and Asp/Mod, giving rise, in addition to the finite (Fin) construction, to various infinitival constructions: Nom-inf, Poss-inf, and PRO-inf. The examples in (1) illustrate, using the same verb remember, the Fin and infinitival constructions in their typical functions. The Fin construction is a clause in the indicative mood, or in a variety of irrealis moods (imperative / jussive / cohortative), and Nom-inf is an irrealis root clause. Poss-inf and PRO-inf are embedded clauses with a variety of functions, and their distribution will be discussed in detail below. ${ }^{1}$ Poss-inf often functions as a temporal adverbial, and PRO-inf_-as a purpose adverbial: ${ }^{2}$

(1) a. Fin

i. Indicative

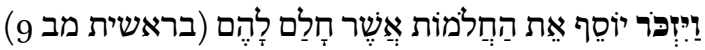

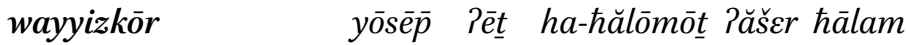
and.remembered.3Ms Joseph ACC the-dreams that dreamt.3Ms lä-hem to-3MP

Then Joseph remembered the dreams which he had dreamed about them. (Gen. 42:9)

ii. Imperative

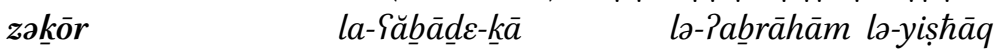

remember.IMPR.2MS to-servants-POSS.2MP to-Abraham to-Isaac u-la-yaৎăqōb

and-to-Jacob

Remember Your servants, Abraham, Isaac, and Jacob. (Deut 9:27)

1 The distinction between these two constructions, which serves the base of the distinction between the Modern Hebrew Gerund and Infinitive, was presented in Doron (2016). This distinction had not been made before in Biblical studies.

2 Unless stated otherwise, all Biblical translations are from the New King James Version (NKJV). The fricative allophones of $b, g, d, k, p, t$ are transcribed as the stop allophone with a diacritic $(\underline{b}, \bar{g}, \underline{d}, \underline{k}, \bar{p}, \underline{t})$. Three vowel qualities are distinguished, in accordance with the Tiberian tradition, e.g. $\bar{a}$ vs. $a$ vs. epenthetic $\breve{a}$. Glosses use the following abbreviations: ACc-Accusative 
b. Nom-inf

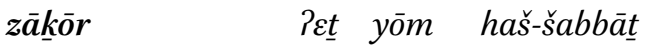

remember.INFABS ACC day.Cs the-sabbath

la-qaddəš-ō

to-sanctify.INF-ACC.3MS

Remember the Sabbath day, to keep it holy. (Ex. 20:8)

c. Poss-inf

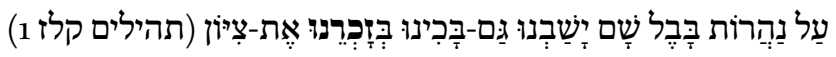
Salnahărōt bābel šām yāšabnū gam bāḳinnū

on rivers.cs Babylon there sat.1P also wept.1P

bə-zok $r$-ēnū PEt sìyyōn

in-remember.INF-Poss.1P ACC Zion

By the rivers of Babylon, there we sat down and wept when we remembered Zion. (Ps. 137:1)

d. PRO-inf

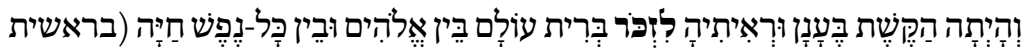

(16 0

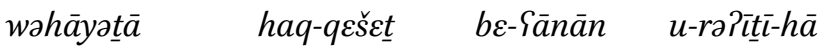

and.be.MOD.3FS the-rainbow.F in.the-cloud and-will.see.1s-ACC.3FS

li-zkōr barīt Sōlām bēn Pělōhìm

to-remember.INF covenant.cs eternity between God

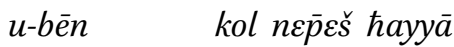

and-between all soul living

The rainbow shall be in the cloud, and I will look on it to remember the everlasting covenant between God and every living creature. (Gen. $9: 16)$

The article is constructed as follows. Section 2 introduces the two allomorphs of the BH infinitive. Section 3 introduces the different infinitival clauses constructed from the infinitive, and their different morphosyntax and distribution. Crucially, the functional categories specifying the infinitive are clausal rather than nominal: an overt or implicit subject Determiner Phrase (DP) is

case; CS—Construct State (morphological marking of the possessee noun); F-Feminine; ILL-Illative case; IMPR-Imperative; INF-Infinitive Construct; INFABS-Infinitive Absolute; Juss-Jussive; M-Masculine; MOD-Modal; NEG-Negation; P-Plural; POss-Possessive case; PTC—Participle; Q-Question particle; S-Singular. 
present. Section 4 further argues for the clausal rather than nominal nature of these constructions, by showing that the infinitive is a verb rather than a noun or a verbal noun - which was the category assigned to it by the traditional literature of the Bible. Section 5 briefly mentions the rise of nominalizations which eventually replaced the Poss-inf structure in post-Biblical Hebrew. Section 6 concludes.

\section{One infinitive category, two allomorphs}

The theoretical issues raised by the $\mathrm{BH}$ infinitive have not yet been tackled. Existing literature assumes two separate infinitives, traditionally called the Infinitive Absolute and the Infinitive Construct. The two are distinguished by their form and distribution, and are described as two separate categories, treated separately in separate chapters of the traditional grammar books of the Bible. $^{3}$

Historically, the Infinitive Absolute is the original infinitive, also found in Akkadian (Blau 1979: §30), while the Infinitive Construct has been claimed to originate in a different Proto-Semitic form, related to the imperfective (Bauer and Leander 1922: $§ 43$ ). Yet, synchronically, I would like to propose that the two are actually syntactically conditioned allomorphs of a single infinitive category of BH. ${ }^{4}$ Derivationally, the Infinitive Absolute is the basic allomorph, as it is found in all the seven Hebrew verbal templates, whereas the Infinitive Construct is only derived in the active and middle templates, but not in the passive. ${ }^{5}$ The derivations are shown in the following table: ${ }^{6}$

3 For example, the Infinitive Absolute is described in Gesenius (1910: §113), Joüon (1923: § 123), and Waltke and O'Connor (1990: §35), whereas the Infinitive Construct is described in Gesenius (1910: §114-115), Joüon (1923: §124), and Waltke and O'Connor (1990: §36).

4 This allomorphy is indistinguishable in some cases from the Absolute vs. Construct state allomorphy in the nominal system. Hence the traditional terminology Infinitive AbsoluteInfinitive Construct, which is otherwise very confusing, since the infinitive is verbal rather than nominal. For example, the noun šâlōm 'well-being' has the construct allomorph šalōm in e.g the possessive construct šalōm Paћckāa 'your brothers' well-being' (Gen. 37:14). This allomorphy identical in form to the allomorphy šāmōr 'observe.INFABS'/ šəmōr 'observe.INF' in the Simple Active template in table 2 (the IN F allomorph is found e.g. in la-biltī šamōr mișwōt$\bar{a} w$ 'by not observing His commandments' (Deut. 8:11)).

5 There are only two potential counterexamples: hulledet 'be-given-birth.INF' in Gen 40:20 and hukkabbēs 'be-laundered.INF' in Lev. 13:55.

6 In addition to the exponents shown in the table, the Infinitive Absolute of some verbs in derived templates also has exponents constructed by analogy to the Simple Active template, e.g. nilћōm 'fight', yassōr 'chasten'. 
(2)

TABLE 1 Templates

\begin{tabular}{|c|c|c|c|c|c|c|}
\hline \multirow{3}{*}{$\begin{array}{l}\text { Voice } \\
\text { Active }\end{array}$} & \multicolumn{6}{|l|}{ Agency } \\
\hline & Simple & & Intensive & & Causative & \\
\hline & $\begin{array}{l}\text { šamōr } \\
\text { observe.INFABS }\end{array}$ & $\begin{array}{l}\text { šamōr } \\
\text { observe.INF }\end{array}$ & $\begin{array}{l}\text { kabbèd } \\
\text { honor.INFABS }\end{array}$ & $\begin{array}{l}\text { kabbēd } \\
\text { honor.INF }\end{array}$ & $\begin{array}{l}\text { haqrē } \underline{b} \\
\text { offer.INFABS }\end{array}$ & $\begin{array}{l}\text { haqrīb } \\
\text { offer.INF }\end{array}$ \\
\hline Middle & $\begin{array}{l}\text { hiššāăbas } \\
\text { vow.INFABS }\end{array}$ & $\begin{array}{l}\text { hiššāăbas } \\
\text { vow.INF }\end{array}$ & $\begin{array}{l}\text { hitnappēl } \\
\text { attack.INFABS }\end{array}$ & $\begin{array}{l}\text { hitnappēl } \\
\text { attack.INF }\end{array}$ & & \\
\hline Passive & & & $\begin{array}{l}\text { gunnōb } \\
\text { be-stolen.INFABS }\end{array}$ & - & $\begin{array}{l}\text { huggēe } \\
\text { be-told.INFABS }\end{array}$ & - \\
\hline
\end{tabular}

The basic allomorph, the Infinitive Absolute, serves as the citation form of the verb, and in adverbial uses (typically bare of arguments). The adverbial infinitive either directly modifies the inflected verb $(3 a-b)$, as described in Callaham 2014, Hatav 2017, and references therein, or it modifies the VP

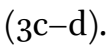

(3) a.

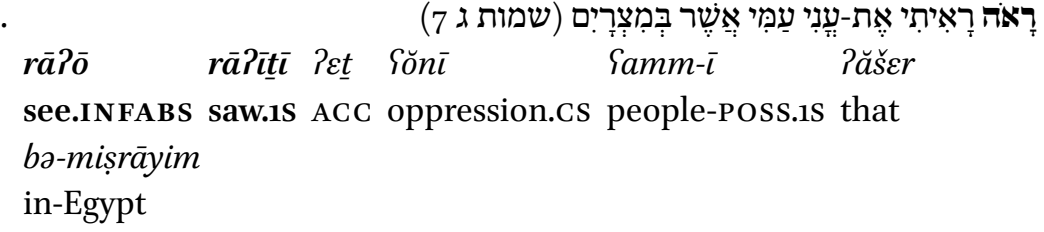

I have surely seen the oppression of My people who are in Egypt. (Ex. 3:7)

b.

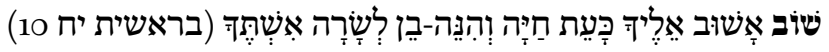
šō $\underline{b}$
?āšū $\underline{b}$

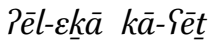
ћayyā

return.INFABS return.MOD.1s to-2Ms as.the-season living

wa-hinnē bèen la-śārā Pišteǩā

and-behold son to-Sarah wife-Poss.2Ms

I will surely return to you when the season comes round again, and

behold, your wife Sarah will have a son! (NET; Gen. 18:10) 
c.

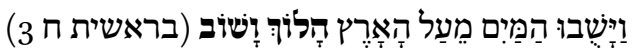
wayyāšubū ham-mayim mē-\{al hā-Pāreș hālōk and.receeded.3MP the-waters from-upon the-earth go.INFABS $\boldsymbol{w} \overline{\boldsymbol{a}}-\bar{s} \bar{o} \underline{b}$ and-return.INFABS

And the waters receded continually from the earth. (Gen. 8:3)

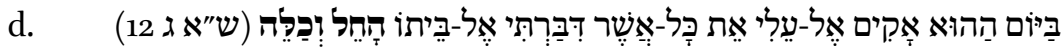

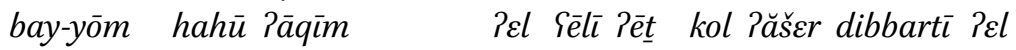
in.the-day that will.perform.1s to Eli ACC all that spoke.1s to bèt-ōo hāhèl wa-kalle house-POss.3Ms begin.INFABs and-end.INFABS

In that day I will perform against Eli all that I have spoken concerning his house, from beginning to end. (1Sam. 3:12)

For the purposes of the present article, I will mostly ignore the adverbial use (3), where the infinitive is "bare" of any functional category, and hence is not clausal and does not introduce a subject. ${ }^{7}$ I will only be interested in the uses of the infinitive which involve clausal constructions with functional categories, and hence a subject. The point of the present article is to show that there are two types of such constructions, one classified together with finite clauses as having conversational force, and the other-as lacking such force. A second dimension classifies clauses as having temporal anchoring, and others as lacking it. We will see the implications of this classification in the next section:

TABLE 2 Typology of infinitival forms

\begin{tabular}{lll}
\hline & + Mood & -Mood \\
\hline$+\mathrm{T}$ & Fin (1a) & Poss-inf (1c) \\
$-\mathrm{T}$ & Nom-inf (1b) & PRO-inf (1d) \\
\hline
\end{tabular}

7 I consider adverbial also the "sequential use", where the Infinitive Absolute, together with its internal arguments, is conjoined to a previous clause and interpreted within the scope of the latter's inflection and subject:

(i)

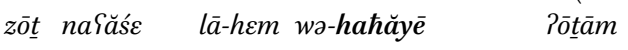

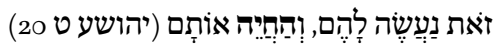

this do.MOD.1P to-3MP and-let.live.INFABs ACC-3MP

This we will do to them: we will let them live (Josh. 9:20). 
The present section discusses the two different uses of the infinitive which involve clausal constructions, i.e. the verb together with all its arguments and functional categories.

\section{1 $\quad[+$ Mood $]$ infinitival clauses}

The first construction is a clause with imperative force (including notional jussive and cohortative). The allomorph of the infinitive in this construction is the Infinitive Absolute. ${ }^{8}$ According to the analysis proposed here, this is due to the fact that the only functional category specified in this construction is Mood, with an [-finite] value interpreted as imperative force. ${ }^{9}$ Since the $\mathrm{T}$ and Asp/Mod categories in the clause are unspecified, there is no inflection to alter the citation form of the infinitive, nor, as we discuss below, to provide an attachment site for subject and object clitics. And as there is no temporal anchoring of the verb to the speech act, these sentences tend to be generic in interpretation unlike the discourse-bound interpretation of the finite imperative (1aii).${ }^{10}$ I will call this construction Nom-inf, since it includes a nominative subject, either a null pro (an addressee-oriented logophoric pronoun according to Portner's 2004 analysis of the imperative), as in (4a), and also (1b) above, or a lexical DP, as in (4b-f), an option found cross-linguistically in imperative clauses (Mauck et al. 2005). As is to be expected of imperative clauses, they are typically root clauses (Palmer 2001). This might be true even when introduced by verba dicendi as in $(4 \mathrm{~d})$, since practically all reported speech in the Bible is direct quotation, constructed as a conjunction of root clauses, which is possible for imperatives as well (Maier 2010).

(4) a.

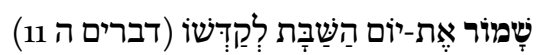
šāmōr Tẹt yōm haš-šabbāt la-qaddəš- $\bar{o}$ observe.INFABS ACC day.cs the-sabbath to-sanctify.INF-ACC.3MS Observe the Sabbath day, to keep it holy. (Deut. 5:11(12))

8 The same is true in Arabic, where the qatäli form which corresponds to the Infinitive Absolute also serves as an imperative (Wright 1874: Vol. 1, p. 62).

9 As is known from the literature (Portner 1997 and references therein), Mood is the category which determines the conversational force of a root clause (Indicative, Imperative, etc.)

10 This contrast is reminiscent of the contrast between the generic $l \bar{o}+$ Modal negation and the eventive ?al+Jussive negation among Fin clauses. 


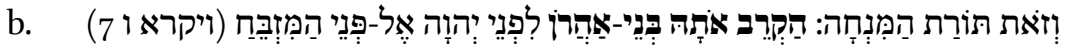

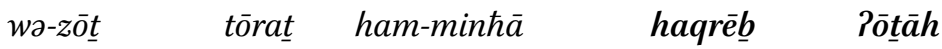
and-this.F (is) law.F.Cs the-grain.offering.F offer.INFABS ACC.3FS

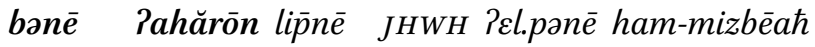
sons.sc Aaron before Lord on the-altar This is the law of the grain offering: The sons of Aaron shall offer it on the altar before the Lord. (Lev. 6:7[14])

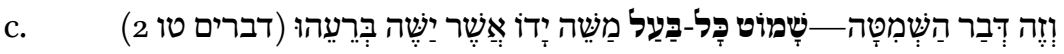
wə-ze dabar haš-šmitțā šāmōt $\quad k o l$ and-this (is) form.M.cs the-release release.INFABs all baSal.maššè.yādo Păšsr yašš $\quad$ bə-rêৎ-ēhu creditor that credit.MoD.3Ms at-peer-Poss.3Ms And this is the form of the release: Every creditor who has lent (anything) to his neighbor shall release (it). (Deut 15:2)

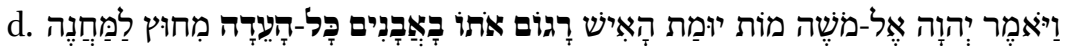

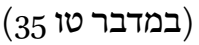
wayyōmer YHWY Pel mōšs mōt yūmat and.said.3Ms Lord to Moses die.INFABs be.made.die.MoD.3Ms

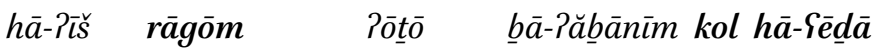
the-man stone.INFABS ACC.3MS with-stones all the-congregation

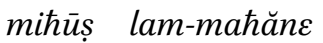
outside to.the-camp Then the Lord said to Moses, the man must surely be put to death; all the congregation shall stone him with stones outside the camp. (Num. $15: 35$ )

e.

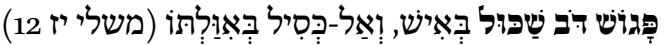
pāāōor dōb šakkūl ba-?īs wa-?al kasīl meet.INFABs bear bereaved at-man and-NEG fool bə-Piwwalt-ō in-folly-Poss.3Ms

Let a man meet a bear robbed of her cubs, rather than a fool in his folly. (Prov. 17:12)

f. אָכּוֹל וְשָׁתוֹ, כִּי מָחָר נָמוּת (ישעיהו כב 13)

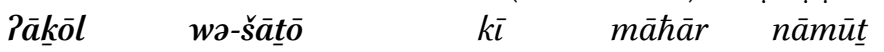
eat.INFABS and-drink.INFABS because tomorrow die.MOD.2P Let us eat and drink, for tomorrow we die. (Is. 22:13) 
I illustrate with simplified structures the Fin vs. Nom-inf imperative, where the former but not the latter includes specification of $\mathrm{T}$ and Asp/Mod functional layers (TAM for short):

(5) a. Fin Imperative (=1a)

zəkōor la-\{ăbā

remember.IMPR.2MS to-servants-POSS.2MP

Remember Your servants ... (Deut 9:27)

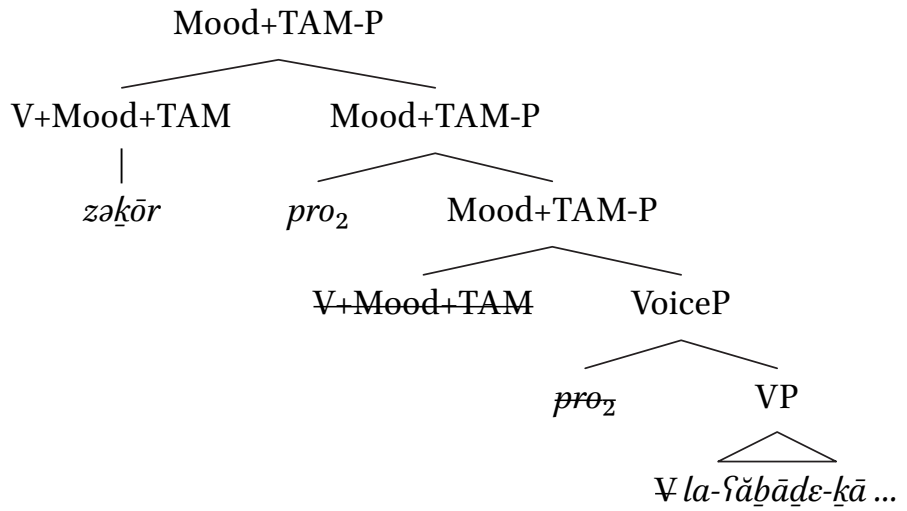

b. Nom-inf Imperative $(=\mathrm{lb})$

$z \bar{a} \underline{k} \bar{o} r \quad$ ie $\underline{t}$ yōm haššsabbāt

remember.INFABS ACC day.CS the-sabbath

Remember the Sabbath day ... (Ex. 20:8)

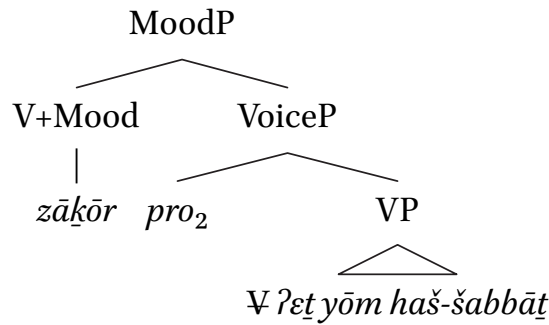




\section{2}

\section{[-Mood] infinitival clauses}

The infinitive allomorph in the second type of construction is the Infinitive Construct. This allomorph allows the attachment of pronominal clitics, something that is strictly disallowed in the Nom-inf construction, built with the Infinitive Absolute allomorph. As we will see below, this difference is due to the fact that subject and object clitics attach to the relevant functional categories - $\mathrm{T}$ and Asp/Mod respectively—which are present in the second type of construction but not in the Nom-inf construction.

The first subtype, familiar from other languages, has a null pronominal anaphor subject (PRO), typically controlled by another DP in the linguistic context. This is the PRO-inf construction. We will see below that it does not have temporal specification, i.e. its T is unspecified, yet it does have Asp/Mod specification. As it is not specified for T, or Mood, the subject is not assigned case, and is hence PRO. As it is specified for Asp/Mod, but not T, it allows object but not subject clitics.

The second subtype, Poss-inf, has an overt subject with possessive case. ${ }^{11} \mathrm{I}$ will argue that this construction is temporal and includes specification of the functional category T, though not of the category Asp/Mod. As it has T specification, but not Asp/Mod, it allows subject but not object clitics. It is distinguished from finite clauses, which have both $\mathrm{T}$ and Asp/Mod specification (and hence both subject and object clitics). I assume that it is non-finite T which assigns possessive case to the subject, in parallel to the non-finite -ing functional category which assigns accusative case to the subject of Acc-ing gerunds in English according to Reuland's 1983 analysis. ${ }^{12}$

In the following examples of PRO-inf and Poss-inf, notice the Infinitive Con-

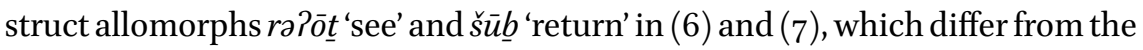
corresponding Infinitive Absolute allomorphs $r \bar{a} P \bar{o}$ and $\check{s} \bar{o} \underline{b}$ of the same verbs in (3) above.

\footnotetext{
11 The possessive case is a marked case of the subject in other languages as well, such as Alaskan Yup'ik (Abney 1987:28), Finnish (Kiparsky 2001), Ladakhi, Lak, Niue (Lander 2011: 59o), Tagalog (Aldridge 2006, Collins 2017), Tzutujil Maya (Abney 1987:31), and others.

12 It has often been noticed that the BH Infinitive Construct subsumes properties of both infinitives and gerunds in other languages. PRO-inf subsumes both the English infinitive and the PRO-ing gerund. Poss-inf parallels the English Acc-ing gerund, despite the morphological difference between accusative and genitive. Poss-inf does not parallel the English Poss-ing, which is a nominal rather than a clausal construction (Pires 2001, 2006, 2007; Moulton 2004).
} 
(6) a. PRO-inf

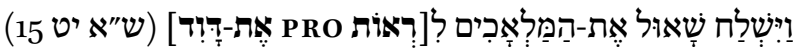

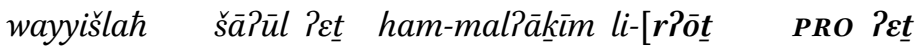
and.sent.3Ms Saul ACC the-messenger to-[see.INF PRO ACC dāwid] $]$

David]

Then Saul sent the messengers back to see David (1Sam 19:15)

b. Poss-inf

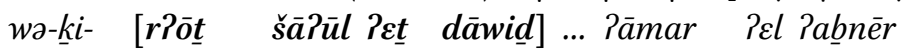
and-as- [see.INF Saul Acc David] said.3Ms to Abner When Saul saw David ..., he said to Abner, (1 Sam. 17:55)

(7) a. PRO-inf

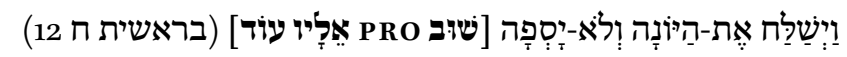

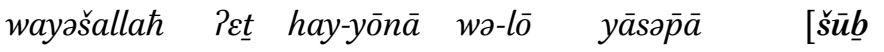
and.sent.3MS ACC the-dove.F and-NEG repeated.3FS [return.INF

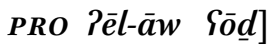
PRO to-3MS anymore]

... and [he] sent out the dove, which did not return again to him anymore. (Gen 8:12)

b. Poss-inf

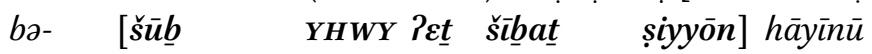

when- [return.INF Lord ACC return.cs Zion] were.2P kə-ћōlmìm

as-dream.PTC.MP

It seemed like a dream when the Lord brought us back to the city of Zion. (CEV; Ps. 126:1)

The possessive case of the Poss-inf subject is overtly marked for pronominal subjects, in particular the 1st person singular and the 3 rd person masculine singular, where the possessive marking differs from accusative marking of the corresponding object clitics in the PRO-inf construction. Thus, the 1st person object clitic $-\bar{e} n \bar{\imath}$ in (8a) differs in form from the ist person subject clitic $-\bar{\imath}$ in (8b), and the 3rd person object clitic - $\bar{e} h \bar{u}$ in (9a) differs in form from the 3 rd person subject clitic $-\bar{o}$ in $(9 b)$ : 
(8) a. PRO-inf

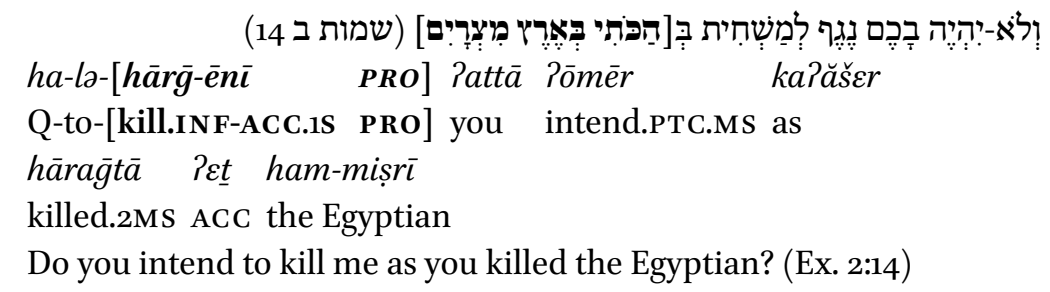

b. Poss-inf

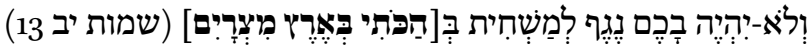

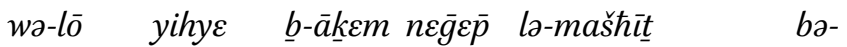
and-NEG be.MOD at-2MP plague to-destroy.PTC.MS when[hakkōt-ī ba-Pereș mișrāyìm] [strike.INF.Poss.1s at-land.cs Egypt]

And the plague shall not be on you to destroy you when I strike the land of Egypt. (Ex. 12:13)

(9) a. PRO-inf

\begin{tabular}{|c|c|}
\hline 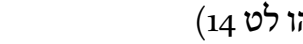 & 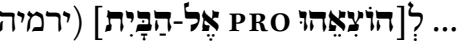 \\
\hline wayyittanū & Pel gadalyāhū ... la- \\
\hline and.committed.3MP & ACC.3MS to Gedaliah ... to- \\
\hline [hōṣi?-ēhū & 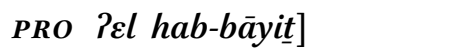 \\
\hline [take.INF-ACC.3MS & PRO to the-house] \\
\hline
\end{tabular}

And they committed him to Gedaliah ... that he should take him home. (Jer. 39:14)

b. Poss-inf

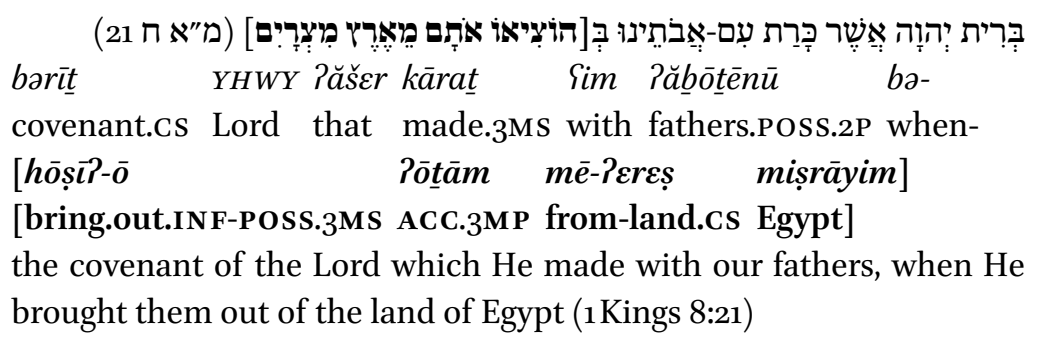

The two constructions contrast sharply in distribution. All the (b) examples in (6)-(9) above are temporal adverbials, and none of the (a) examples are. This is not an accident, as it is the case in general that temporal prepositions only take Poss-inf complements, never PRO-inf complements. I attribute this to fact that Poss-inf clauses include T specification in their structure, whereas PRO- 
inf clauses do no. Thus only the former can serve as the Specifier of the main clause Thead (Cinque 1999). PRO-inf clauses function as purpose clauses, as in (6a) and (9a), i.e. they are Asp/Mod phrases (AM for short) which are adjuncts to the Asp/Mod head of the main clause:13,14

(10) a. Poss-inf

Spec of T: temporal adverbial (cf. 6b)

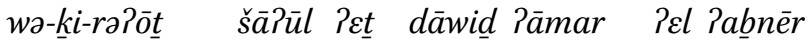

and-as-see.INF Saul ACC David said.3Ms to Abner

When Saul saw David, he said to Abner (1Sam. 17:55)

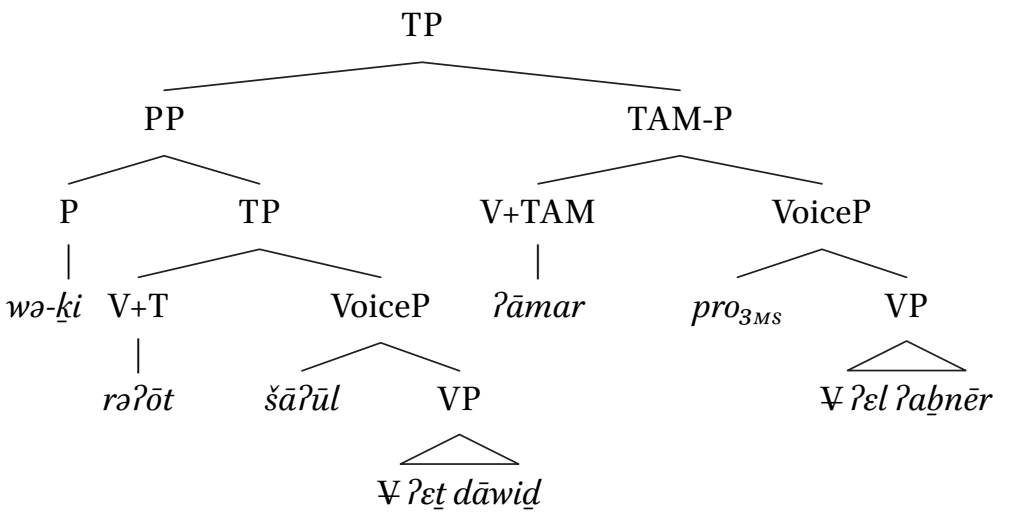

13 Purpose clauses are part of infinitival clauses which "are a group which displays a characteristic future-oriented, irrealis semantics" (Portner 1997: 183). Yet, as argued by Wurmbrand (2001, 2014), the seeming temporal relation of the infinitival clause to the main clause is not due to T but to Mod, which determines the inherent future orientation of purposes.

14 Purpose clauses are distinct from rationale clauses (Jones 1985, Verstraete 2008), which can be expressed by the Poss-inf construction. The latter describes a result event, as in (i) below, not necessarily the outcome and agent's intentions, unlike the intentional/modal characterization of purpose clauses:

(i) Poss-inf: rationale clause

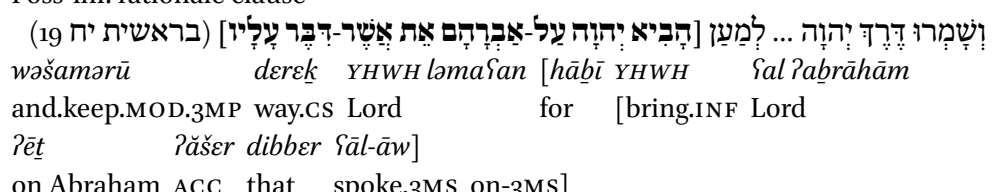

that they keep the way of the Lord, ..., that the LorD may bring to Abraham what He has spoken to him (Gen. 18:19)

One syntactic difference which distinguishes purpose and rationale clauses is that only the former allow an additional controlled empty category (glossed as $e_{j}$ in the following example): 
b. PRO-inf Spec of Asp/Mod: purpose adverbial

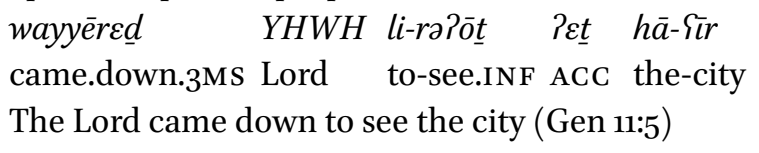

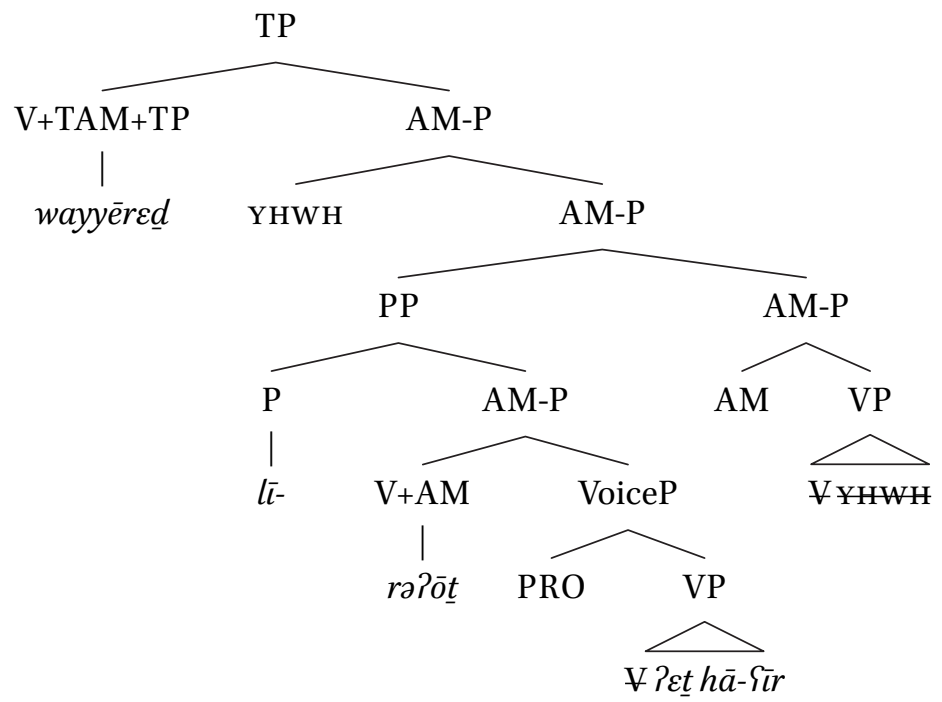

Infinitival clauses also function as complements, and as such are selected by different types of verbs. Poss-inf clauses are propositional TPs, and are hence selected by propositional attitude verbs, such as know (Gen. 19:35, Jer. 15:15), remember (Jer. 2:2, 18:20), consent (Gen. 19:21), hear (1Sam 14:27), see (Is. 52:8), illustrated in (11a). PRO-inf clauses are Asp/ModP, and hence complements of aspectual verbs, e.g. begin (Judg. 20:39), repeat (1Sam 15:35), stop (1Sam. 23:13), finish (Lev. 16:20), ${ }_{15}^{15}$ or modal verbs such as be able (Deut 7:22),

(ii) PRO-inf: purpose clause

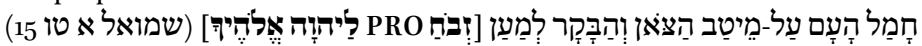

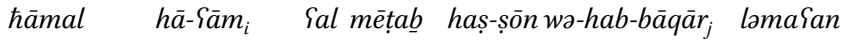
spared.3ms the-people ${ }_{\mathrm{i}}$ on best.cs the-cattle and-the-beef $\mathrm{j}_{\mathrm{j}}$ to

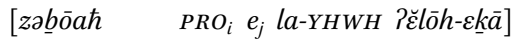
[sacrifice.INF $\mathrm{PRO}_{\mathrm{i}} e_{\mathrm{j}}$ to-Lord God-POsS.2Ms]

The people spared the best of the sheep and the oxen to sacrifice to the Lord your God (1Sam. 15:15).

15 ter Meulen (1995) notes that aspectual verbs such as begin, stop, continue, can have infinitival complements if they describe an event-external change. 
want (1Sam. 19:2), intend (Ex. 2:14), plan (Deut. 19:19), refuse (Num. 20:21), give up (1Sam. 27:1), order (2Sam. 17:14), prevent (Num. 22:16), illustrated in $(11 b){ }^{16}$

(11) a. Poss-inf

Complement of propositional attitute verb

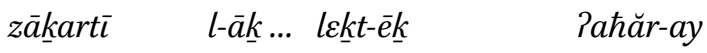

remember.1s to-2Fs go.INF-POSS.2Fs behind-1S

I remember your following me (Jer. 2:2)

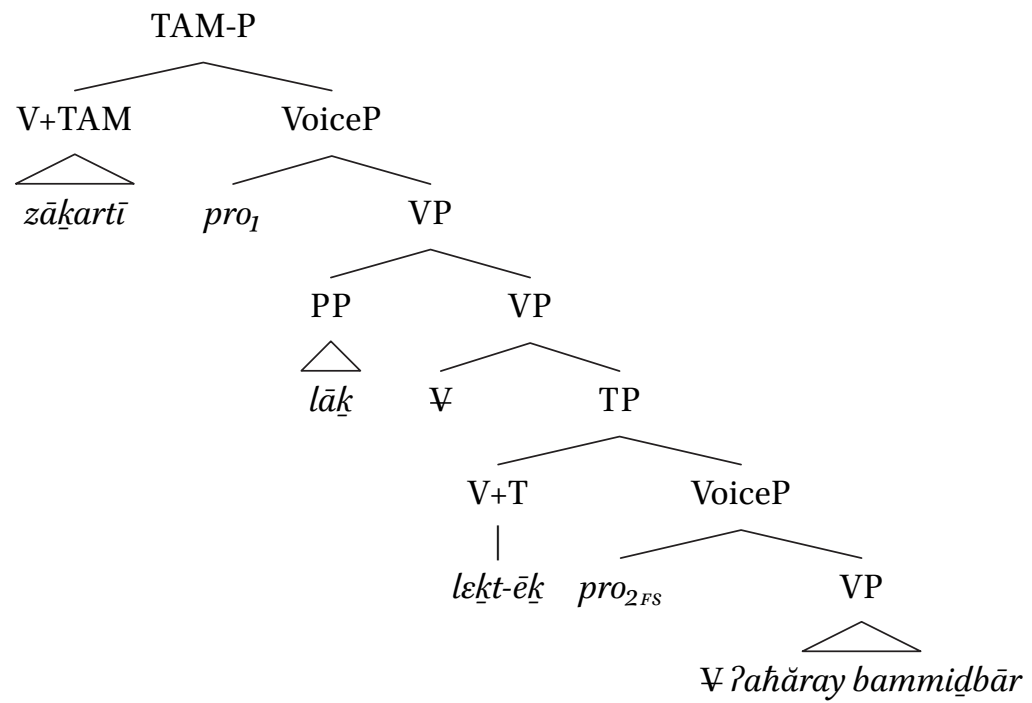

b. PRO-inf

Complement of Modal/Aspectual verb

Pattā Pōmēr la-horḡ-ēnì

you intend.PTC to-kill.INF-ACC.1S

You intend to kill me. (Ex. 2:14) cf. (8a)

16 Additional examples are given in Doron (2018). 


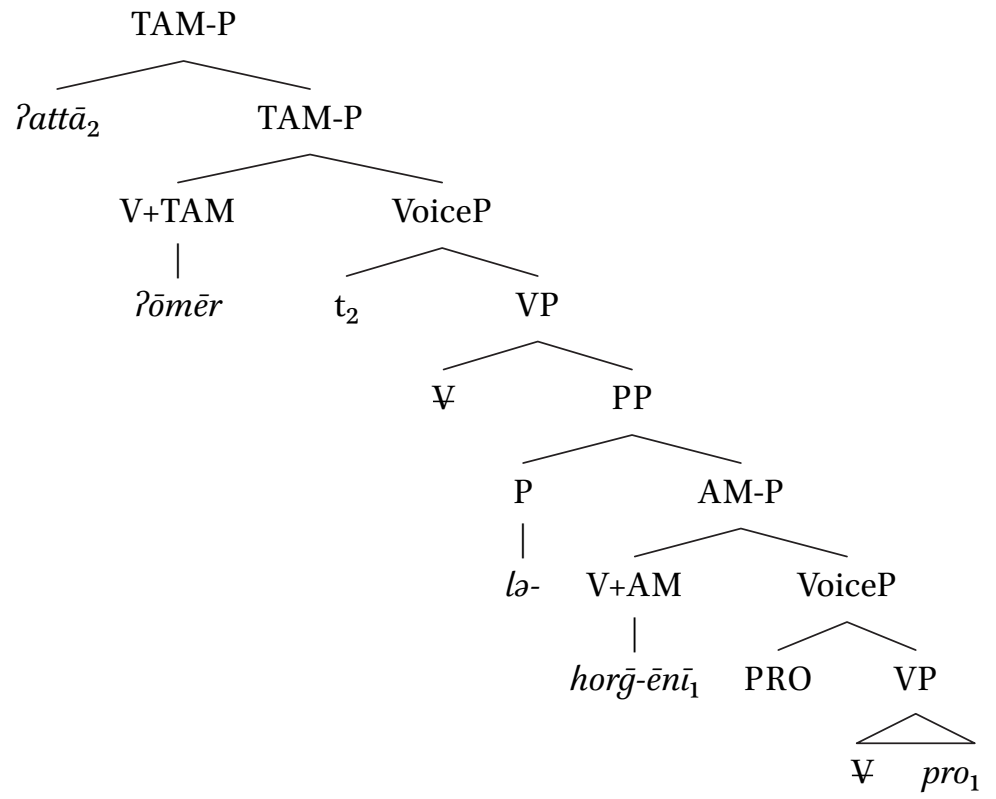

Aspectual and modal verbs in the (11b) structure are control verbs expressing root modality (Ability, Deontic). When the same verbs modify the aspectual and modal dimension of a state/event which is not determined by the actions or abilities of an agent, their modality is interpreted as alethic (metaphysical), they do not have an agent, and function as raising verbs (Hacquard 2011). The following examples describe the beginning (a), repetition (b), possibility (c) of an event/state, independently of an agent. The non-agentive subject of the complement raises from the infinitival clause, leaving a trace $(t)$ which is an empty category different from PRO, yet like PRO is restricted to case-less positions:

(12) a.

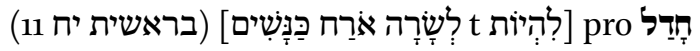

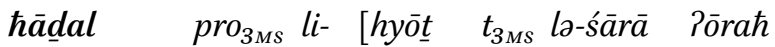

ceased.3Ms pro $_{3 \mathrm{MS}}$ to- [be.INF $\mathrm{t}_{3 \mathrm{MS}}$ to-Sarah period.M

kan-nāš̀m]

as.the-women]

Sarah had passed the age of childbearing (Gen. 18:11)

b.

wat.tōse $\overline{\boldsymbol{p}}$

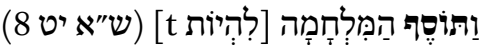

and.recurred.3Fs the-war.F to- [be.INF $\left.t_{3 \mathrm{~F}}\right]$

And there was war again (Gen. 19:8) 
c.

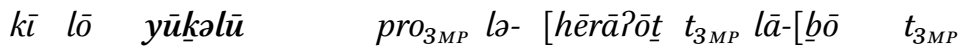
for NEG can.MOD.3MP pro pMP $_{3 \mathrm{M}}$ to- [be-seen $\mathrm{t}_{3 \mathrm{MP}}$ to-[come $\mathrm{t}_{3 \mathrm{MP}}$ $\left.h \bar{a}-\varsigma_{i} r-\bar{a} \quad\right]$ the-city.ILL ] because they could not be seen entering the city. (MEV; 2 Sam. 17:17)

(13) Complement of a raising Modal/Aspectual verb

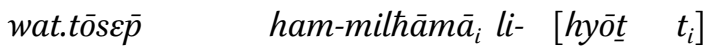
and.recurred.3Fs the-war. $\mathrm{F}_{\mathrm{I}}$ to- [be.INF $\mathrm{t}_{\mathrm{i}}$ ] And there was war again (Gen. 19:8)

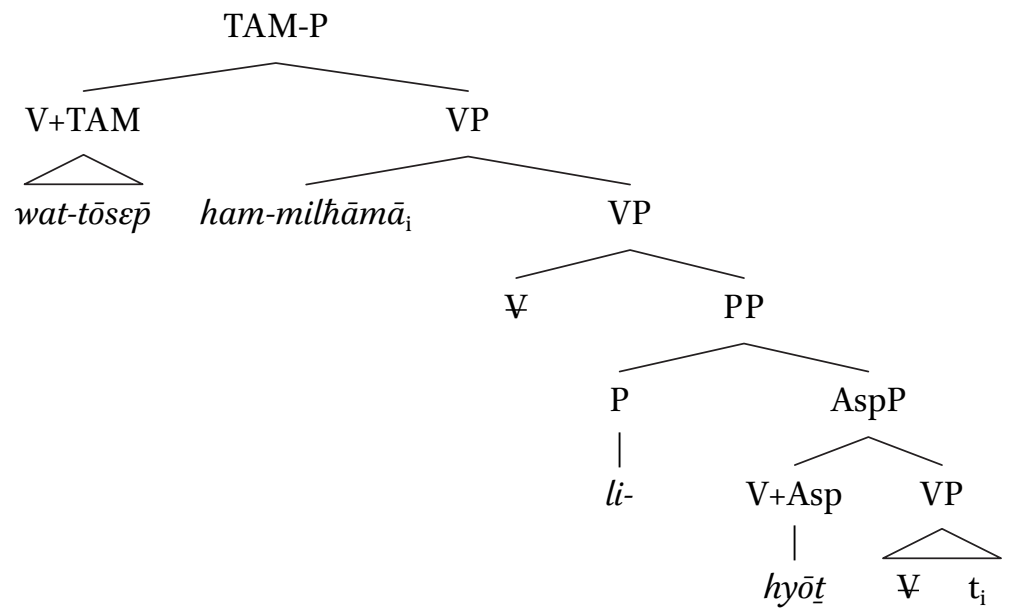

The importance of the examples in (12) is in demonstrating the clausal nature of infinitives with null subjects.

\subsection{The morpho-syntax of the various verb forms}

Unlike the Nom-inf construction, which is restricted to root clauses, the PROinf and Poss-inf constructions are embedded clauses, i.e. never have conversational force of their own. This fact has been encoded by their including no specification of the functional category Mood. Yet they can acquire conversational force and function as main clauses through a fronted wh-element such as $m a$ 'what' in (14): 
(14)

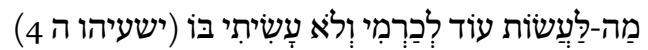
mal- la- [乌ăsóōt PRo ९ōd la-karm-ī ] wa-lō what to- [do.INF PRO more to-vineyard-POsS.1s ] and-NEG did.1S $b-\bar{o}$ in-3Ms

What more could have been done to My vineyard that I have not done in it? (Is. 5:4)

Another morphosyntactic distinction has been attributed above to the categories $\mathrm{T}$ and Asp/Mod-i.e. the variation between the different infinitive constructions, and the contrast between them and the Fin construction, in allowing the cliticization of subject and object pronouns as part of the morphology of the verb. The following table summarizes the allowed cliticization options in the different constructions, and examples are given in (16)-(17) below:

\section{(15)}

TABLE 3 Distribution of clitics

\begin{tabular}{lll}
\hline & + Subj cl. & - Subj cl. \\
\hline + Obj cl. & Fin & PRO-inf \\
- Obj cl. & Poss-inf & Nom-inf \\
\hline
\end{tabular}

The verb in the PRO-inf construction can have object clitics (16b, 17b) but clearly not subject clitics, since, for case reasons, it does not have an overt subject of any kind. On the other hand, the verb in the Poss-inf construction can have an overt object. But crucially—not in the form of a clitic $(16 \mathrm{c}, 17 \mathrm{c})$. This is surprising, since both subject and object clitics appear with a Fin verb (16a, 17a):

(16) a. Fin

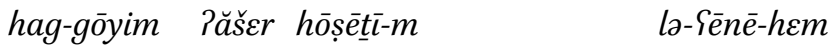

the peoples that brought.out.1s-ACC.2MP to-eyes-Poss.3MP

the Gentiles, in whose sight I had brought them out (Eze. 20:14) 
b. PRO-inf
la-hōṣị?-ām
$m \bar{e}-$ Perss
to-bring.out.INF-ACC.3MP from-land.cs Egypt
for bringing them out of the land of Egypt (Ex. 12:42)

(שמות יב

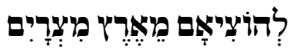

c. Poss-inf

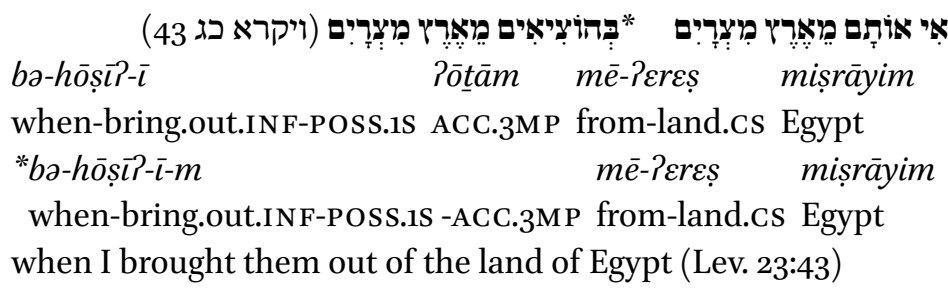

(17) a. Fin

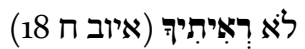

lō raPītit-kēa

NEG saw.1S-ACC.2MS

I have not seen you (Job 8:18)

b. PRO-inf

wayyābōo ham-melek li-r?ōt-ō

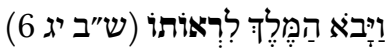

came.3Ms the-king to-see.INF-ACC.3MS

the king came to see him (2Sam. 13:6)

c. Poss-inf

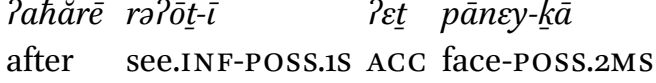

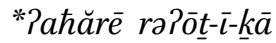

after see.INF-POSS.1S-ACC.2MS

since I have seen your face (Gen. 46:30)

The ungrammaticality in the (c) examples above is not due to "heaviness" of two combined clitics, since even if the subject is not a pronominal clitic but a full lexical item, an object clitic is impossible in the Poss-inf construction: 
(18) Poss-inf

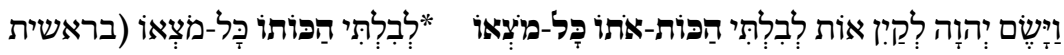
(15 ד

wayyāśsm YHWH la-qayin Pōt lo-beiltī hakkōt Poțō kol and.put.3MS Lord to-Cain mark to-NEG kill.INF ACC.3MS any mōṣ̂-ō

find.PTC.Ms-Poss.3Ms

And the Lord set a mark on Cain, lest anyone finding him should kill him. (Gen. 4:15)

*la-bilttī hakkōt-ōo kol mōṣ̂-ōo

to-NEG kill.INF-ACC.3MS any find.PTC.MS-POss.3MS

(19) Poss-inf

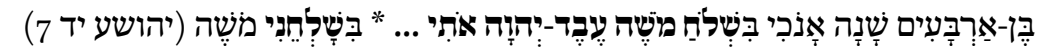

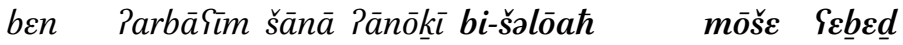
son.cs forty year I when-send.INF Moses servant.cs JHWH Pōtī

Lord ACc.1S

I was forty years old when Moses the servant of the LoRD sent me ... (Josh. 14:7)

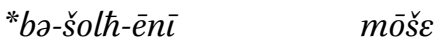

when-send.INF-ACC.1s Moses

The ban against an object clitic in the Poss-inf construction is thus not morphophonological but morphosyntactic. I have assumed that it is the functional category Asp/Mod which licenses the object clitic, both in the Fin clause and in the PRO-inf clause. The Asp/Mod category is unspecified in the Poss-inf construction, hence the lack of object clitics. As has often been remarked in the literature, object clitics attach to inflection which is characteristically verbal (e.g. in Romance, Cardinaletti and Shlonsky 2004). ${ }^{17}$

I summarize in (21) the morpho-syntactic characteristics of the different finite and infinitival clauses, where the relevant functional categories are ordered by the hierarchy in $(20)$ :

17 Indeed the participle, which is inflected as a noun, mostly takes genitive marked object clitics: 
(20) Mood $<$ T $<$ Asp $/$ Mod $<$ Voice

TABLE 4 Summary

\begin{tabular}{lllllllll}
\hline & $\begin{array}{l}\text { Phrasal } \\
\text { category }\end{array}$ & $\begin{array}{l}\text { Projected by } \\
\text { functional categories }\end{array}$ & $\begin{array}{l}\text { Mood } \\
\text { morphology }\end{array}$ & Verb & $\begin{array}{l}\text { Subj. } \\
\text { case }\end{array}$ & $\begin{array}{l}\text { Subj. } \\
\text { clitic }\end{array}$ & $\begin{array}{l}\text { Obj. } \\
\text { clitic }\end{array}$ \\
\hline Fin clause & TAM-P & + Mood+T+Asp/Mod & \pm Indic. & Finite & Nom & + & + \\
Nom-inf & MoodP & + Mood-T-Asp/Mod & - Indic. & Inf. Abs. & Nom & - & - \\
Poss-inf & TP & - Mood+T-Asp/Mod & - & Inf. Constr & Poss & + & - \\
PRO-inf & Asp/Mod & - -Mood-T+Asp/Mod & - & Inf. Constr & - & - & + \\
\hline
\end{tabular}

The Hebrew grammatical tradition, ever since the Rabbinic and Karaite grammars of the middle ages, views the infinitive absolute as verbal, and the infinitive construct as nominal (Eldar 2014, Gaash 2018). The European grammatical tradition views both infinitives as mixed nominal/verbal categories (Gesenius 1910, Joüon 1923, Waltke and O'Connor 199o, Arnold and Choi 2003, and others). But, as already argued in Doron (2018), a careful analysis shows that the infinitive is verbal, and has no nominal properties whatsoever. This claim can actually be substantiated on two counts. First, the lexical category of the infinitive is $\mathrm{V}$ rather than N, not even a deverbal N. Second, the functional categories specifying $\mathrm{V}$ are clausal rather than nominal—similarly to what has been shown by

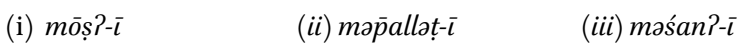

find.PTC.MS-Poss.1s deliver.PTC.MS-POss.1s hate.PTC.MS-POss.1s

(iv) šôlh-ì

send.PTC.MS-POsS.1S

'anyone who finds me' (Gen. 4:14); 'He delivers me' (Ps. 18:49); 'he who hates me' (Job 31:29); 'He who sent me' (2 Sam. 24:13)

Yet the participle exhibits noun/verb duality, and there are also a few cases where it heads a finite clause with accusative object clitics:

$h \bar{a}-P \bar{e} l$

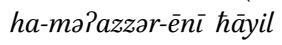

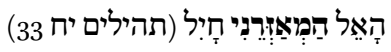

the-God that-arm.PTC.MS-ACC.1s strength

It is God who arms me with strength (Ps. 18:33[32]). 
Pires (2001), (2006), (2007) for the English PRO-ing and Acc-ing gerunds, i.e. that they are clausal rather than nominal. ${ }^{18}$

First, the infinitive assigns accusative case to its direct object, as could be seen in all the examples above, where the infinitive had a direct object. ${ }^{19}$ Moreover, object clitics attached to the infinitive are always accusative rather than genitive. In the case of nominal forms, such as the participle, one mostly finds genitive object clitics (fn. 18).

Second, the infinitive has no nominal morphological inflection of gender, number, or definiteness. ${ }^{20}$ The infinitive is case marked in a few examples by the accusative $? \varepsilon \underline{t}$, as in (22a), but so are Fin CPs as in (22b):

(22) a.

wว-șett-əkূ̄a $u-\underline{b} \bar{o} P-\bar{a} k \bar{a}$

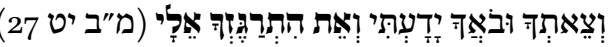

and-go.out.INF-POsS.2Ms and-come.in.INF-POsS.2Ms knew.1s

wa-?ēt hitraggez-kāa ièlāy

and-ACC rage.INF-POsS.2Ms at-1S

But I know ... your going out and your coming in, and your rage against Me. (2 Kings 19:27)

b.

$z \partial \underline{k} \bar{o} r$

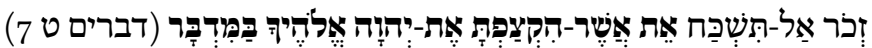

remember.IMPR.2MS NEG forget.JUSS.2MS ACC that

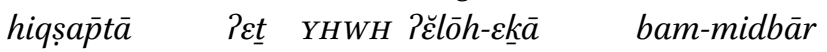

provoked.2Ms ACC Lord God-Poss.2ms in.the-desert

Remember! Do not forget how you provoked the Lord your God to wrath in the wilderness (Deut. 9:7)

18 In English, Poss-ing gerunds are nominal.

19 Modern Hebrew allows nominalized verbs to assign accusative case as well, which is a marked option crosslinguistically. This phenomenon originates in Medieval Hebrew under Arabic influence (Blau 199o, Goshen-Gottshtein 1951/2006). Yet it is not found in Biblical Hebrew, where forms such as ?ahăba 'love', which were later recategorized as nouns, are still infinitives:

(i)

bə-Pahăbat $\quad$ YHWH Pet

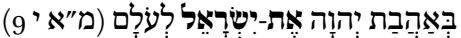

because-love.INF Lord ACC Israel forever

Because the LoRD has loved Israel forever (1 Kings 10:9).

20 There are few cases where the infinitive happens to have feminine morphology, such as love in the previous footnote. There are even fewer cases where the infinitive is preceded by the article the. 
Third, the infinitive is not modified by adjectives but by adverbs, such as the

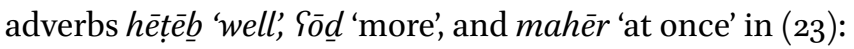

(23) a.

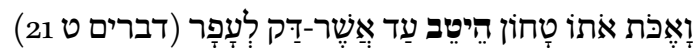

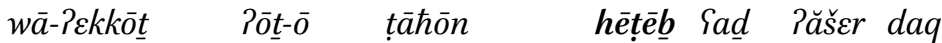
and-crushed.1s ACC-3MS grind.INFABs well until that fine la- $\hat{\text { āp } \bar{a} r}$ to-dust ... and crushed it and ground it very small, until it was as fine as dust (Deut. 9:21)

b.

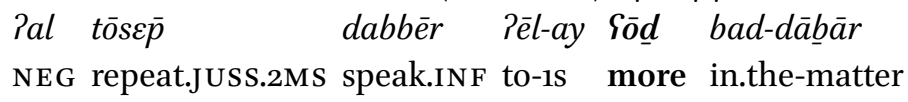
$h a z-z \varepsilon$ the-this Speak no more to Me of this matter (Deut. 3:26)

c.

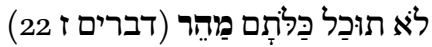
lo tūkal kallōt-ām mahēr NEG be.able.MOD.2Ms destroy.INF-ACC.3MP at.once you will be unable to destroy them at once (Deut. 7:22)

Fourth, despite the genitive case marking of its subject, the infinitive in the Poss-inf construction is not a noun. It does not head a construct state phrase. Unlike the nominal construct where the construct state (CS) noun must be absolutely adjacent to its complement, the same is not true of the infinitive in the Poss-inf construction. No adjacency required. The subject of the infinitive is separated from the verb in many examples, something which never happens in a construct. This is exemplified in the following examples where the subject is separated from the infinitive verb hakkot in (24a) by the accusative pronoun ?ōtōo, similarly in the other examples in (24):

(24) a.

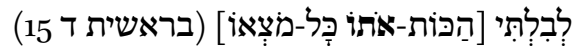

la-biltī [hakkōt Sōtōo kol mōṣ̂-ō]

to-NEG [kill.INF ACC.3Ms any find.PTC-Poss.3Ms]

... lest anyone finding him should kill him. (Gen. 4:15) 
b.

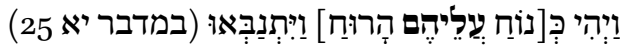

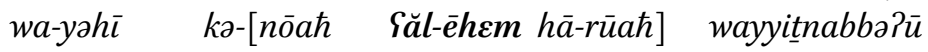
and-was.3M as-[rest.INF on-3MP the-spirit] and.prophesized.3MP and it happened, when the Spirit rested upon them, that they prophesied (Num. 11:25)

c.

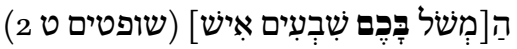

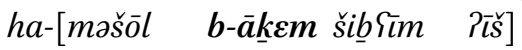
Q-[reign.INF at-2MP seventy man] [Which is better for you] that all seventy ... reign over you ...? (Judg. $9: 2)$

d.

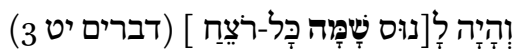
wa.hāyā lā-[nūs šàmmā kol rọṣea $]$ will.be.3Ms to-[flee.INF there any murder.PTc.ms] that any manslayer may flee there (Deut. 19:3)

We now turn to showing that embedded infinitival clauses have the distribution of embedded clauses rather than nominal projections. They are found as complements of prepositions, but only prepositions which take clausal arguments, including Fin CPs, for example the preposition kə — 'as' expressing similarity:

(25) a.

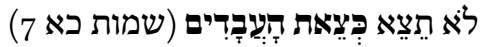

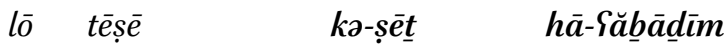
NEG go.out.MOD.3FS as-go.out.INF the.slaves.MP she shall not go out as the male slaves do (Ex. 21:7)

b.

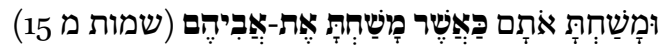
umāš $a \hbar t \bar{a}$

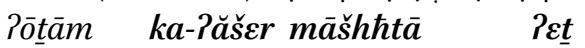
annoint.MOD.2MS ACC.3MP as-that annointed.2MS ACC Păbihsm father-Poss.3MP

You shall anoint them, as you anointed their father (Ex. 40:15)

Prepositions like Sim 'with', which only take DPs complements and do not take Fin-CP complements, also do not take infinitival clauses. On the other hand, prepositions like yaian 'since', which do not take nominal complements in Classical BH but do take Fin-CPs, also take infinitival clauses: 


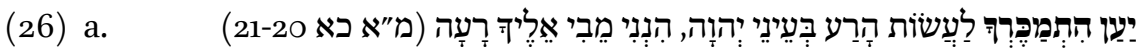

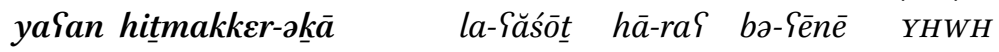
since betook.INF-Poss.2Ms to-do.INF the-evil in-eyes.CS YHWH

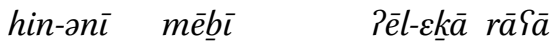
behold-1s bring.PTC.Ms to-2Ms calamity Because you have sold yourself to do evil in the sight of the Lord, behold, I will bring calamity on you. (2 Kings 21:20-21)

b.
yaSan kī niknas since that submitted.3
$h \bar{a}-r \bar{a} \rho \bar{a} \quad b \partial-y \bar{a} m-\bar{a} w$ the-calamity in-days-Poss.3Ms
Because he has humbled himself before Me, I will not bring the calam- ity in his days. (1 Kings 21:29)

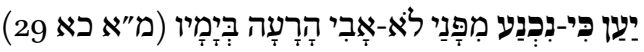

The quantifier kol 'all', typically constructed with noun phrases, is found in the construct with infinitival clauses, but so it is with Fin CPs:

(27) a.

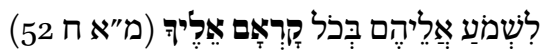

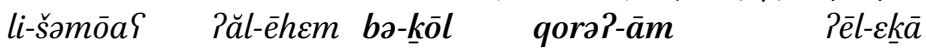
to-listen.INF to-3MP when-any call.INF-POsS.3MP to-2MS to listen to them whenever they call to You (1 Kings 8:52)

b.

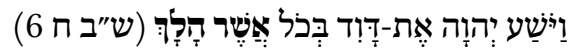
wayyōša $\quad Y H W H$ PEt dāwid bo-kōl Păšer hälāk and.saved.3Ms Lord ACC David where-any that went.3MS So the LORD preserved David wherever he went (2 Sam. 8:6)

Other nouns, such as yōm 'day', which are constructed to infinitival clauses, are also constructed to Fin CPs:

(28) a.

lamaian tizkōr

for remember.MOD.2MS ACC day.CS exit.INF-Poss.2Ms me-PEreș mișrayim

from-land.cs Egypt

that you may remember the day in which you came out of the land of Egypt (Deut 16:3) 
b.

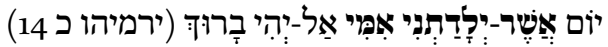
yom Păǎšr yolādatitni
Pimm- $\bar{\imath}$
ral yahi

day that bore.3MS-ACC.1S mother-Poss.1S NEG be.JUSS.3MS

bārū $\underline{k}$

blessed

Let the day not be blessed in which my mother bore me!

Moreover, like Fin CPs, infinitival clauses function as relative clauses. (29a) has a Fin CP relative clause, (29b) — a PRO-inf relative clause, and (29c) - a Possinf relative clause.

(29) a. Fin

$\begin{array}{lll}\text { kol bāśār Păšer yaqrībū } & \text { la-YHWH } \\ \text { all flesh [that bring.MOD.3MP to-Lord t] }\end{array}$

all flesh which they bring to the Lord (Num. 18:15)

b. PRO-inf

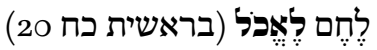

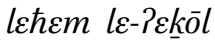

bread to-[eat.INF t]

bread to eat (Gen. 28:20)

c. Poss-inf

mayim li- štōt $h \bar{a}-\varsigma \bar{a} m$

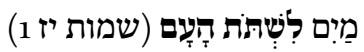

water to- [drink.INF the-people $t$ ]

water for the people to drink (Ex. 17:1)

Finally, negation is found with infinitival clauses, and it can be shown to take scope over the entire clause rather than just modifying the infinitival head. Only clausal scope can give the correct reading in (30). Sacrificing to the Lord is the purpose of sending off the people, not the purpose of not-sending off the people. Therefore, negation attaches to the full clause letting the people go to sacrifice to the Lord rather than to the head letting go. In Modern Hebrew, the negative bilti has grammaticalized into a prefix which attaches to lexical items, in particular adjectives. 


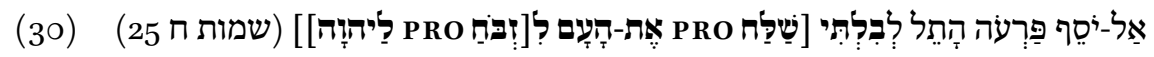

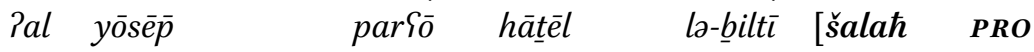

NEG repeat.Juss.3MS Pharaoh deceive.INF to-NEg [send.InF PRo

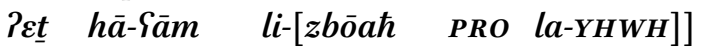

ACC the-people to sacrifice PRO to-Lord]]

But let Pharaoh not deal deceitfully anymore in not letting the people go to sacrifice to the Lord. (Ex. 8:25[29])

\section{$5 \quad$ The emergence of event nominals}

As this paper has demonstrated, Biblical Hebrew makes heavy use of the infinitive. This correlates with the dearth of event nominals in the Bible. Yet their number increases towards late Biblical Hebrew, in the Second Temple period, a tendency that multiplies in Rabbinic Hebrew (Ben-Asher 1976), where they completely supersede the Poss-Inf construction.

Event nominals often started off as nouns referring to concrete entities, and their abstract event denotation developed later. In the Bible, the noun malk üt for example is not interpreted as 'reign', but as 'kingdom'. In this early interpretation, it does not have an argument structure, but, which is interesting, probably neither does it have argument structure under the event interpretation, which it later developed. In other words, even under the later interpretation it functions as a Simple Event Nominal in the terminology of Grimshaw (1990). Indeed, event nominals in the Bible, and also in $\mathrm{RH}$, never have accusativemarked direct objects, which only emerged in Medieval Hebrew. Biblical eventexpressions assigning accusative case are not event nominals but infinitives (cf. footnote 20 ).

The following examples illustrate the replacement of the infinitive in the Poss-inf construction in the early Bible (the book of Kings), by the event nominal (in the book of Chronicles, late Biblical Hebrew).

(31) a. Poss-inf

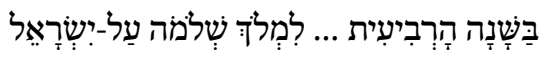

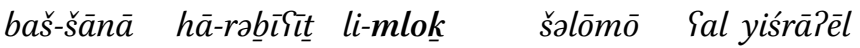

in.the-year the-fourth to-reign.INF Solomon on Israel

in the fourth year of Solomon's reign over Israel (1Kings 6:1) 
b. Event Nominal

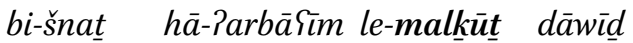 \\ in-year.cs the-forty to-reign.cs David \\ In the fortieth year of the reign of David (1Chronicles 26 31)
}

Late Biblical Hebrew also saw a blurring of the distinction between the two allomorphs of the infinitive (Absolute and Construct), as reported by Fassberg (2007), Morrison (2013), Mor (2015, to appear), and others. Rabbinic Hebrew has a single infinitive allomorph, different from both Biblical allomorphs, and its distribution is that of the Biblical PRO-inf.

It seems reasonable to assume that it was the collapse of the Mood specification in the verbal system of post-Biblical Hebrew, which launched the demise of the Nom-inf construction. As to the replacement of Poss-inf by event nominalization, this is not a trivial development. I conjecture it could have been due to the introduction into Hebrew of the category D, which could have replaced the category $\mathrm{T}$ as the head of propositional event complement/adjuncts, favouring combination with event nouns rather than infinitive verbs. This will hopefully be the topic of further research.

\title{
$6 \quad$ Conclusion
}

The article has shown how the morphosyntax of the different infinitival clauses determines their distribution. Nom-inf clauses are root clauses with irrealis Mood, hence have the conversational force of imperatives. PRO-inf and Possinf clauses are not specified for Mood, and thus have no conversational force. They therefore must be embedded clauses. The lack of $T$ specification, in addition to the lack of Mood specification, determines that the PRO-inf clause cannot be interpreted as an independent proposition, but is rather interpreted as part of the event denoted by the main clause, since it depends for its temporal anchoring on the temporal specification of the main clause. The Asp/Mod specification of the PRO-inf construction allows it to function as complement of aspectual and modal verbs, and as adjunct to Mod/Asp heads, i.e. as purpose clauses. The Poss-inf clause, on the other hand, contains a specification of $\mathrm{T}$, and hence denotes a separate proposition from the one denoted by the main clause. Accordingly, it functions as a complement of propositional attitude verbs or a temporal / rationale / result adjunct. The specification of $\mathrm{T}$ and/or Asp/Mod in an infinitival clause has also been shown to explain the various possibilities of subject and object cliticization in the various clauses. 
In sum, the paper has shown that the same functional categories which determine the inflection of the Biblical Hebrew finite verb also determine the feature specification of the Biblical Hebrew infinitive.

\section{Acknowledgments}

I am grateful to the audiences of the July 2016 Conference on the Emergence of Modern Hebrew at The Mandel Scholion Research Center. The Hebrew University of Jerusalem, and the February 2018 Conference on Biblical Hebrew: Advances in Grammar and Lexicology at the Academy of the Hebrew Language, Jerusalem. For much inspiration, I am grateful to Susi Wurmbrand's lectures at the HUJI/TAU Winter School in Syntax at the Hebrew University of Jerusalem, December 2017.

\section{References}

Abney, Steven. 1987. The English noun phrase in its sentential aspect. Ph.D. dissertation, MIT.

Aldridge, Edith. 2006. Absolutive case in Tagalog. Proceedings from the Annual Meeting of the Chicago Linguistic Society 42.2. 1-15. Chicago: Chicago Linguistic Society.

Arnold, Bill T. and John H. Choi. 2003. A Guide to Biblical Hebrew Syntax. Cambridge: Cambridge University Press.

Bauer, Hans and Pontus Leander. 1922. Historische GrammatikDer Hebräischen Sprache Des Alten Testaments. Halle: M. Niemeyer.

Ben-Asher, Mordechai. 1976. On the infinitive and nomen actionis in biblical and modern Hebrew. in Chaim Rabin Jubilee Volume: Ki-leshon 'ammo-Studies in Applied Linguistics. ed. by Ben-Zion Fischler \& Raphael Nir.Jerusalem: Council for the Teaching of Hebrew. 23-35. [in Hebrew]

Blau, Yehoshua. 199o. Hebrew and Arabic. Leshonenu La'am 40.5: 311-335. [in Hebrew]

Blau, Yehoshua. 1979. The Phonology and Morphology of Biblical Hebrew. Second edition 2010, Jerusalem: The Academy of the Hebrew Language.

Callaham, Scott N. 2014. Modality and the Biblical Hebrew Infinitive Absolute. Wiesbaden: Harrassowitz Verlag.

Cardinaletti, Anna and Ur Shlonsky. 2004. Clitic positions and restructuring in Italian. Linguistic Inquiry 35.4: 519-557.

Cinque, Guglielmo. 1999. Adverbs and Functional Heads: A Cross-Linguistic Perspective. Oxford: Oxford University Press.

Collins, James. 2017. Structure Sensitive Interpretation: A Case Study in Tagalog. Stanford PhD Dissertation. 
Cook, John A. 2006. The Finite Verbal Forms in Biblical Hebrew do Express Aspect. JANES 30: 21-35.

Cook, John A. 2012. Time and the Biblical Hebrew Verb: The Expression of Tense, Aspect, and Modality in Biblical Hebrew. Winona Lake IN: Eisenbrauns.

Doron, Edit. 2016. The sources of Modern Hebrew syntax. Lecture presented at the Conference on the Emergence of Modern Hebrew. The Mandel Scholion Research Center. The Hebrew University of Jerusalem.

Doron, Edit. 2018. The infinitive construct as a verbal form. Proceedings of the conference Biblical Hebrew: Advances in Grammar and Lexicology. Jerusalem: Academy of the Hebrew Language. [in Hebrew]

Eldar, Ilan. 2014. The History of Hebrew Linguistics in the Middle Ages: the Andalus School. Jerusalem: The Academy of the Hebrew Language. [in Hebrew]

Fassberg, Steven. 2007. The Overlap in Use Between the Infinitive Construct and the Infinitive Absolute in Biblical Hebrew, in Shai Le-Sara Japhet: Studies in the Bible, Its Exegesis and Its Language, ed. M. Bar-Asher et al. Jerusalem: Bialik Institute. 427-433 [in Hebrew]

Gaash, Amir. 2018. Infinitives and Nominalizations in the Bible according to Karaite Grammatical Treatise Me'or Ayin. Proceedings of the conference Biblical Hebrew: Advances in Grammar and Lexicology. Jerusalem: The Academy of the Hebrew Language. [in Hebrew]

Gesenius, Wilhelm. 1910. Gesenius' Hebrew Grammar, as Edited and Enlarged by E. Kautzsch. Translated by A.E. Cowley. Oxford: Clarendon Press.

Givón, Talmy. 1980. The binding hierarchy and the typology of complements. Studies in Language 4.3: 333-377.

Goshen-Gottstein, Moshe H. 20o6. Syntax and Vocabulary of Medieval Hebrew: Under the Influence of Arabic. Jerusalem: Ben-Zvi Institute, edited and published by Shraga Assif \& Uri Melammed on the basis of the unpublished ${ }_{1951}$ PhD diss. [in Hebrew]

Grimshaw, Jane. 199o. Argument structure. Cambridge, Massachusetts: MIT Press.

Hacquard, Valentine. 2011. Modality. In C. Maienborn, K. von Heusinger, and P. Portner (eds.) Semantics: An International Handbook of Natural Language Meaning. HSK 33.2. Berlin: Mouton de Gruyter. 1484-1515.

Hatav, Galia. 1997. The Semantics of Aspect and Modality: Evidence from English and Biblical Hebrew. Amsterdam: John Benjamins.

Hatav, Galia. 2008. The modal system of Biblical Hebrew. in G. Hatav (ed.) Theoretical Hebrew Linguistics. Jerusalem: The Hebrew University Magnes Press. 163-191. [in Hebrew]

Hatav, Galia. 2017. "The Infinitive Absolute and Topicalization of Events in Biblical Hebrew". Advances in Biblical Hebrew Linguistics: Data, Method, and Analyses, ed. A. Moshavi \& T. Notarius. Eisenbrauns. 207-229.

Johnson, K. 1988. Clausal Gerunds, the ECP, and Government. Linguistic Inquiry 19:4. 583-6og. 
Jones, Charles. 1985. Agent, patient, and control into purpose clauses. in W.H. Eilfort, P.D. Kroeber, \& K.L. Peterson (eds.) Papers from the Parasession on Causatives and Agentivity at the Twenty-First Regional Meeting, Vol. 21.2, Chicago, IL: Chicago Linguistic Society. 105-119.

Joosten, Jan. 2002. Do Finite Verbal Forms in Biblical Hebrew Express Aspect? JANES 29: 49-70.

Joüon, Paul. 1923. Grammaire de l'Hébreu Biblique. Rome: Institut Biblique Pontifical. Kiparsky, Paul. 2001. Structural case in Finnish. Lingua 111: 315-376.

Lander, Yury. 2011. Varieties of genitive. In A. Malchukov and A. Spencer (eds.) The Oxford Handbook of Case. Oxford: Oxford University Press. 581-592.

Maier, Emar. 2010. Quoted imperatives. In Martin Prinzhorn, Viola Schmitt and Sarah Zobel (eds.) Proceedings of Sinn und Bedeutung 14: 289-304. University of Vienna.

Mauck, Simon, Miok Pak, Paul Portner \& Raffaella Zanuttini. 2005. Imperative subjects: A Cross-linguistic Perspective. Georgetown University Working Papers in Theoretical Linguistics ed. by C. Brandstetter, \& D. Rus. Georgetown University Press. 135-152. ter Meulen, Alice. 1995. Representing Time in Natural Language. Cambridge: MIT Press. Mor, Uri. 2015. One more look at the negation of the Infinitive Construct in Second Temple Hebrew. Vetus Testamentum: 65. 437-456.

Mor, Uri. to appear. The Predicative Infinitive Construct in Second Temple Hebrew. Variation and Change in Language, ed. Ruth Berman, Jerusalem: the Israel Academy of Sciences and Humanities [in Hebrew].

Morrison, Craig E. 2013. Infinitive: Biblical Hebrew. in Encyclopedia of Hebrew Language and Linguistics, Vol. 2. ed. by G. Khan. Leiden: Brill.

Moulton, Keir. 2004. External arguments and gerunds. Toronto Working Papers in Linguistics 22: 121-136.

Palmer, Frank R. 2001. Mood and Modality. Second Edition. Cambridge: Cambridge University Press.

Pires, Acrisio. 2001. Clausal and TP-Defective Gerunds: Control without tense. In Proceedings of NELS 3 1. GLSA, University of Massachusetts, Amherst. 386-406.

Pires, Acrisio. 2006. The Minimalist Syntax of Defective Domains: Gerunds and Infinitives. Amsterdam: John Benjamins.

Pires, Acrisio. 2007. The derivation of clausal gerunds. Syntax 10.2:165-203.ll

Portner, Paul. 1997. The semantics of mood, complementation, and conversational force. Natural Language Semantics 5: 167-212, 1997.

Portner, Paul. 2004. The semantics of imperatives within a theory of clause types. in R. Young (ed), SALT XIV. $235^{-25}$

Reuland, Eric J. 1983. Governing -ing. Linguistic Inquiry 14.1: 101-136.

Verstraete, Jean-Christophe. 2008. The status of purpose, reason, and intended endpoint in the typology of complex sentences: implications for layered models of clause structure. Linguistics 46.4: 757-788. 
Waltke, Bruce K. and Michael P. O'Connor. 1990. An Inroduction to Biblical Hebrew Syntax. Winona Lake, IN: Eisenbrauns.

Wright, W. 1896. A Grammar of the Arabic Language. Third Edition. Cambridge: Cambridge University Press.

Wurmbrand, Susi. 2001. Infinitives: Restructuring and Clause Structure. Berlin: Mouton de Gruyter.

Wurmbrand, Susi. 2014. Tense and aspect in English infinitives. Linguistic Inquiry 45.3: 403-447. 